\title{
Changes in the mineral composition of soybean xylem sap during monocarpic senescence and alterations by depodding
}

\author{
L. D. Noodén and C. S. Mauk
}

\begin{abstract}
Noodén, L. D. and Mauk, C. S. 1987. Changes in the mineral composition of soybean xylem sap during monocarpic senescence and alterations by depodding. - Physiol. Plantarum 70: 735-742.
\end{abstract}

\begin{abstract}
Evidence from earlier studies with explants (stem cutting with a leaf and a pod) indicates that a decline in the supply of mineral nutrients from the roots may prepare the leaves for induction of monocarpic senescence in soybean [Glycine max (L.) Merrill $\mathrm{cv}$. Anoka]. In order to assess the changes in mineral flux from the root system, xylem sap was collected from a decapitated plant under $100 \mathrm{kPa}$ pressure over $50 \mathrm{~min}$. The sap volume yield declines after flowering starts, but increases during pod extension and then decreases again during podfill. The concentrations of $\mathrm{K}, \mathrm{Ca}, \mathrm{Mg}, \mathrm{P}, \mathrm{S}$, $\mathrm{Zn}, \mathrm{Fe}, \mathrm{Mn}, \mathrm{Cu}, \mathrm{Mo}$ and $\mathrm{Si}$ rise and then fall during reproductive development, but the exact timing differs among the elements. In contrast, $\mathrm{B}, \mathrm{Al}$ and $\mathrm{Na}$ concentrations show a slow rise initially with a large increase in late pod development. Depodding, which prevents the early death of the plant, inhibits the changes of some elements (K, $\mathrm{Mg}$ ) but not others ( $\mathrm{Ca}, \mathrm{Mg}, \mathrm{P}, \mathrm{S}, \mathrm{Zn}, \mathrm{Fe}, \mathrm{Mn}, \mathrm{B}, \mathrm{Cu}, \mathrm{Al})$, and it does not prevent the decrease in sap volume delivered. Inasmuch as the mineral concentration of xylem sap quantitatively reflects upward mineral flux, the supply of most minerals to the shoot declines, and this decrease seems to be an important factor in the preparatory phase of monocarpic senescence. The different minerals show different patterns of change, which indicate differences in the transport mechanisms and their regulation.
\end{abstract}

Additional key words - Glycine max, mineral nutrients, mineral transport.

L. D. Noodén (corresponding author) and C. S. Mauk, Biology Dept, Univ. of Michigan, Ann Arbor, MI 48109-1048, USA.

\section{Introduction}

Monocarpic senescence is the degeneration leading to the death of a plant following its reproductive phase (Noodén 1980b). In soybean, monocarpic senescence is induced by the developing seeds, which appear to act primarily on the leaves (Noodén 1980a). A syndrome of degenerative changes occurs not only in the leaves, but elsewhere including the roots (Noodén 1980b, 1984). While root growth ceases and net mineral accumulation declines during monocarpic senescence in soybean (Ohlrogge 1963, Harper 1971, deMooy et al. 1973, Derman et al. 1978, Noodén 1980b), it is difficult to assess the importance of these changes in the overall process of whole plant senescence. A direct approach, which we have employed, is to excise the root system and study the contribution of its products, cytokinin and minerals, to maintenance of foliar functions and pod development by substituting defined solutions for the roots (Neumann et al. 1983, Noodén 1985). Using explants consisting of a leaf and a subtending stem segment with or without pods, we have shown that depriving the explants of its normal mineral nutrient and cytokinin supply (e.g. placing the explants in water) does not itself cause senescence of the leaf. In fact, the pods cause senescence of the leaves; however, supplying high levels of mineral nutrients and cytokinin through the xylem may override the action of the pods (Neumann et al. 1983, Garrison et al. 1984, Noodén 1985). Thus, it appears that a decline (preparatory phase) in the flux of minerals and cytokinin from the roots via the xylem is necessary for the pods to induce senescence.

The present study examines directly the changes in xylem sap mineral concentrations during the reproduc- 


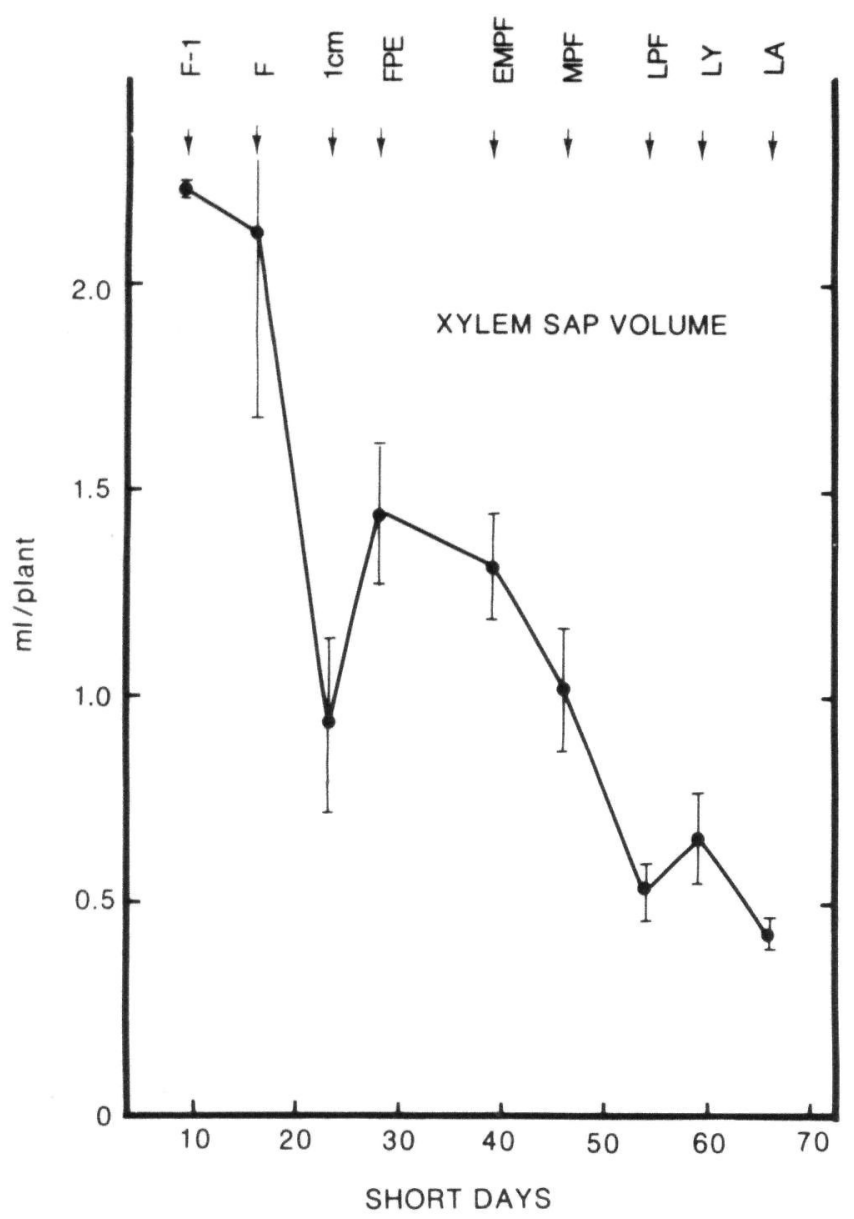

Fig. 1. Changes in xylem sap volume during the soybean's reproductive phase. Collected over a 50 -min period from plants decapitated at various stages and subjected to $100 \mathrm{kPa}$ of pressure. Abbreviations: F-1 refers to 1 week before flowering, F to the start of flowering, $1 \mathrm{~cm}$ to most advanced pods $1-\mathrm{cm}$ long, FPE to full pod extension (pre-podfill), EMPF to early-mid podfill, MPF to mid podfill, LPF to late podfill, LY to leaf yellowing and LA to leaf abscission. SEs are shown.

tive phase, including senescence, of the soybean. Since depodding prevents the rapid death of the plant (Leopold et al. 1959, Noodén 1980b), we also studied the effect of depodding on xylem sap minerals.

\section{Materials and methods}

\section{Plant culture}

Soybean plants [Glycine $\max$ (L.) Merrill] cv. Anoka were inoculated and grown in pots of soil as previously described (Lindoo and Noodén 1976). The plants were cultured on a greenhouse bench under long days (extended to midnight with high pressure sodium vapor lamps) until the first trifoliate leaves had unfolded. The plants were then transferred into environmental control chambers with short $(10-\mathrm{h})$ days $\left(26^{\circ} \mathrm{C}\right.$ days and $21^{\circ} \mathrm{C}$ nights). These plants, watered with tap water containing $1.1 \mathrm{~g}^{-1}$ Peters (Peters Fertilizer Products, W. R. Grace and Co., Fogelsville, PA 18051) standard water-soluble fertilizer $[20 \%(\mathrm{w} / \mathrm{w}) \mathrm{N}, 8.7 \% \mathrm{P}, 3.4 \% \mathrm{~K}]$ every 2 weeks during early growth or 2-3 days before sap collection to ensure high mineral levels in the soil.

\section{Xylem sap collection}

Plants used for xylem sap collection were watered exactly $1 \mathrm{~h}$ before decapitation and were used only during a 2-h period around midday. Xylem sap was collected by cutting off the shoot $8 \mathrm{~cm}$ above the soil level (well below the lowest leaves) and then placing the potted stock in a sealed chamber with the cut stem emerging through the top. Using a compressed air line, $100 \mathrm{kPa}$ was applied continuously to the chamber. The first drop of exudate was wiped off, and thereafter the sap was collected in cleaned, low-potassium-glass liquid scintillation vials for $50 \mathrm{~min}$. The rate of sap flow declined rapidly just before this time. The samples were then frozen and lyophilized in the same vials.

Sap was collected at key developmental stages (Fig. 1) from 1 week before flowering through leaf abscission. In this report, flowering refers to the start of petal display. Some plants were depodded from full pod extension (before the start of podfill) and sap collected at early-mid podfill or early leaf yellowing. Others were depodded at late podfill and collected at early leaf yellowing. Each datum point represents the pooled average of sap from at least 3 plants; data points with SE are based on 3-4 pooled batches drawn from 9-12 plants.

\section{Mineral analyses}

Most of the samples were analyzed with a Jerral Ash ICAP 9000 inductively coupled argon plasma spectrophotometer at the Plant Analysis Lab, Oregon State Univ., Corvallis, OR, although one set (data not shown) was measured with an atomic absorption spectrophotometer in the Plant and Soil Sciences Analytical Lab. at the Univ. of Maine, Orono, ME. These latter data were similar to those shown here in the figures.

\section{Results}

Changes in sap volume

The sap volume exuded during a 50-min interval under $100 \mathrm{kPa}$ pressure decreased from flowering through very early pod development and rose slightly during pod 


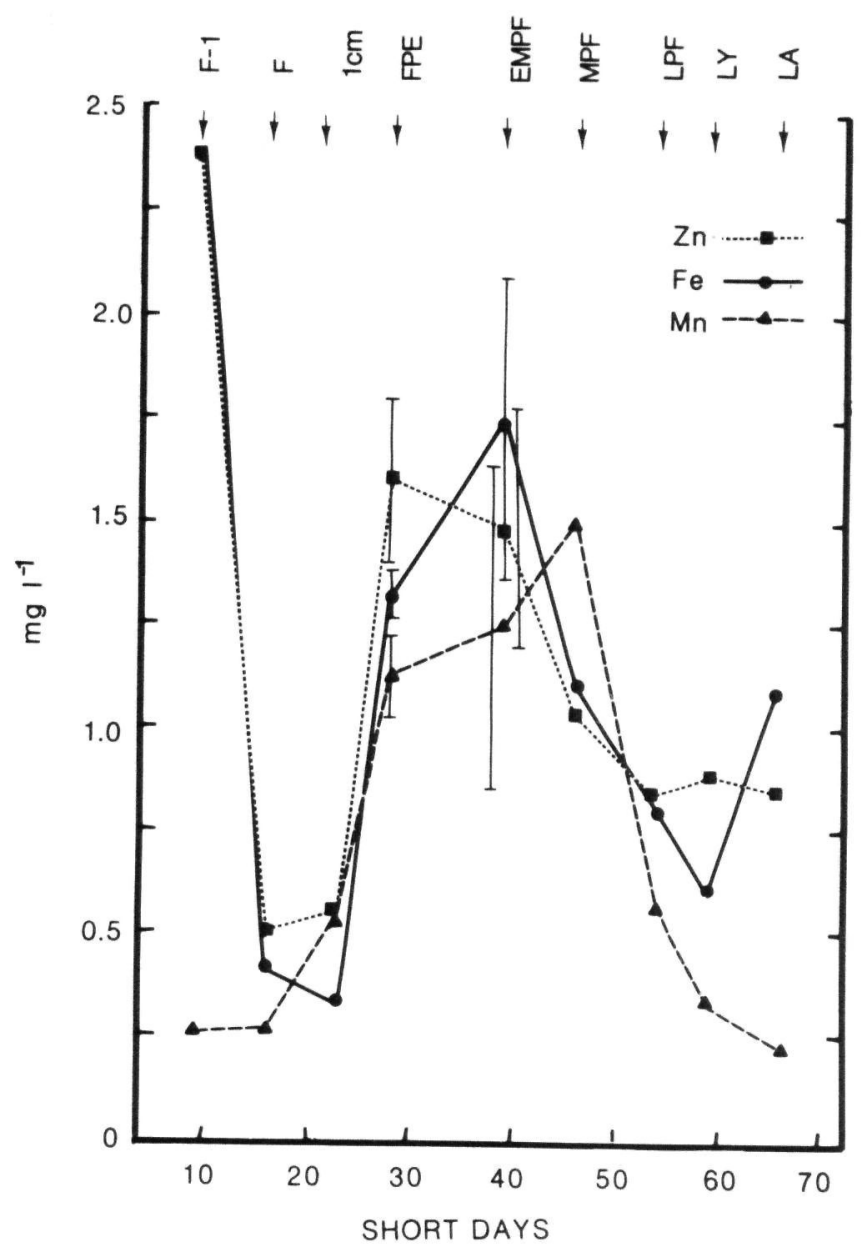

Fig. 2. Changes in the concentration of $\mathrm{Zn}, \mathrm{Fe}$ and $\mathrm{Mn}$ in xylem sap during the soybean's reproductive phase. Procedure and $a b$ breviations as in Fig. 1.

extension (Fig. 1). The volume fell again during podfill and levelled off between late podfill and leaf abscission. In another experiment, both the rise and fall began about 2 weeks earlier, at 1 week before flowering and at full pod extension, respectively (data not shown).

Changes in element concentration in xylem during
reproductive development

The profiles for the different minerals are grouped into different figures mainly according to concentrations. $\mathrm{Zn}$ and $\mathrm{Fe}$ showed time course patterns very similar to the sap volume except that their concentrations decreased a bit earlier, before flowering (Fig. 2). None of the other elements showed this large drop in concentration just preceding reproductive development; however, this could have taken place before our measurements started at 1 week before flowering. Most $(\mathrm{K}, \mathrm{Ca}, \mathrm{Mg}, \mathrm{P}$, $\mathrm{Zn}, \mathrm{Fe}, \mathrm{Mn}, \mathrm{Mo}$ and $\mathrm{Si}$ ) showed a pattern of rise and fall with minor variations during reproductive develop- ment. Mn, Zn, Fe (Fig. 2), K, Ca (Fig. 3), Mg, P and S (Fig. 4) all rose sharply just before full pod extension. $\mathrm{Cu}$ (Fig. 5) rose earlier, while Mo (Fig. 5) and $\mathrm{Si}$ (Fig. 6) rose later. Clearly, these elements differed in when they peaked and in their profiles over time. K (Fig. 3) started decline after full pod extension, whereas Mg, P (Fig. 4), Mo (Fig. 5) and Si (Fig. 6) began after early-mid podfill. Mn (Fig. 2) started later, at mid podfill, while Ca (Fig. 3 ) seemed to begin later, perhaps between mid and late podfill. In some other experiments (e.g. Tab. 1), Zn did not decrease during podfill, while $\mathrm{Fe}$ declined only slightly. Some (Fe in Fig. 2, $\mathrm{Si}$ in Fig. 6) rose again slightly during leaf yellowing or abscission. The last sampling times (early leaf yellowing and leaves abscised) showed more difference among plants (e.g. SE in Tab. 1), and this was reflected in the visible symptoms of senescence. S (Fig. 4) and Cu (Fig. 5) showed more complex patterns of rise and fall, and also more variability among experiments. In another experiment (data not shown), these two elements show a more typical rise and fall, with $\mathrm{Cu}$ peaking at flowering and $\mathrm{S}$ at full pod extension.

B, Na, (Fig. 6) and $\mathrm{Al}$ (Fig. 7) behaved quite differ-

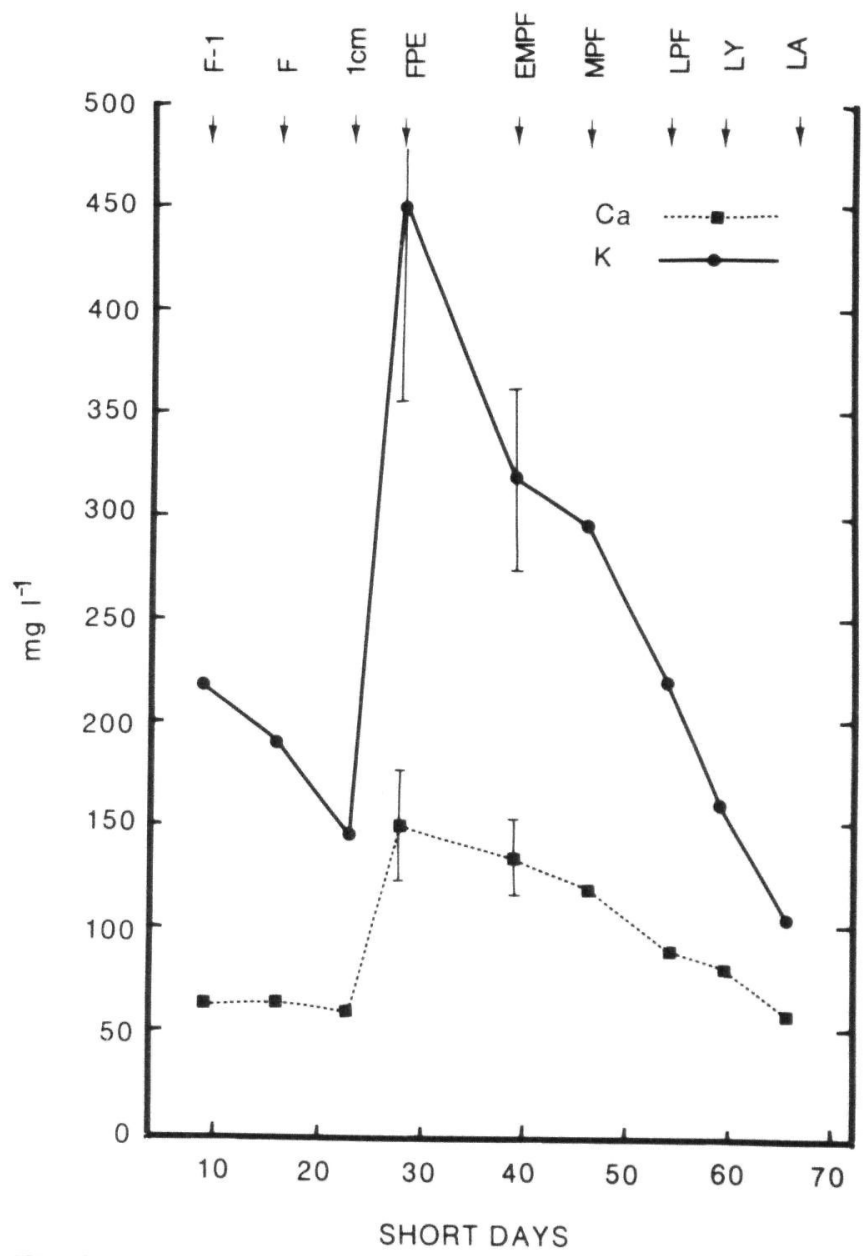

Fig. 3. Changes in the concentration of $C a$ and $K$ in xylem sap during the soybean's reproductive phase. Procedure and abbreviations as in Fig. 1. 


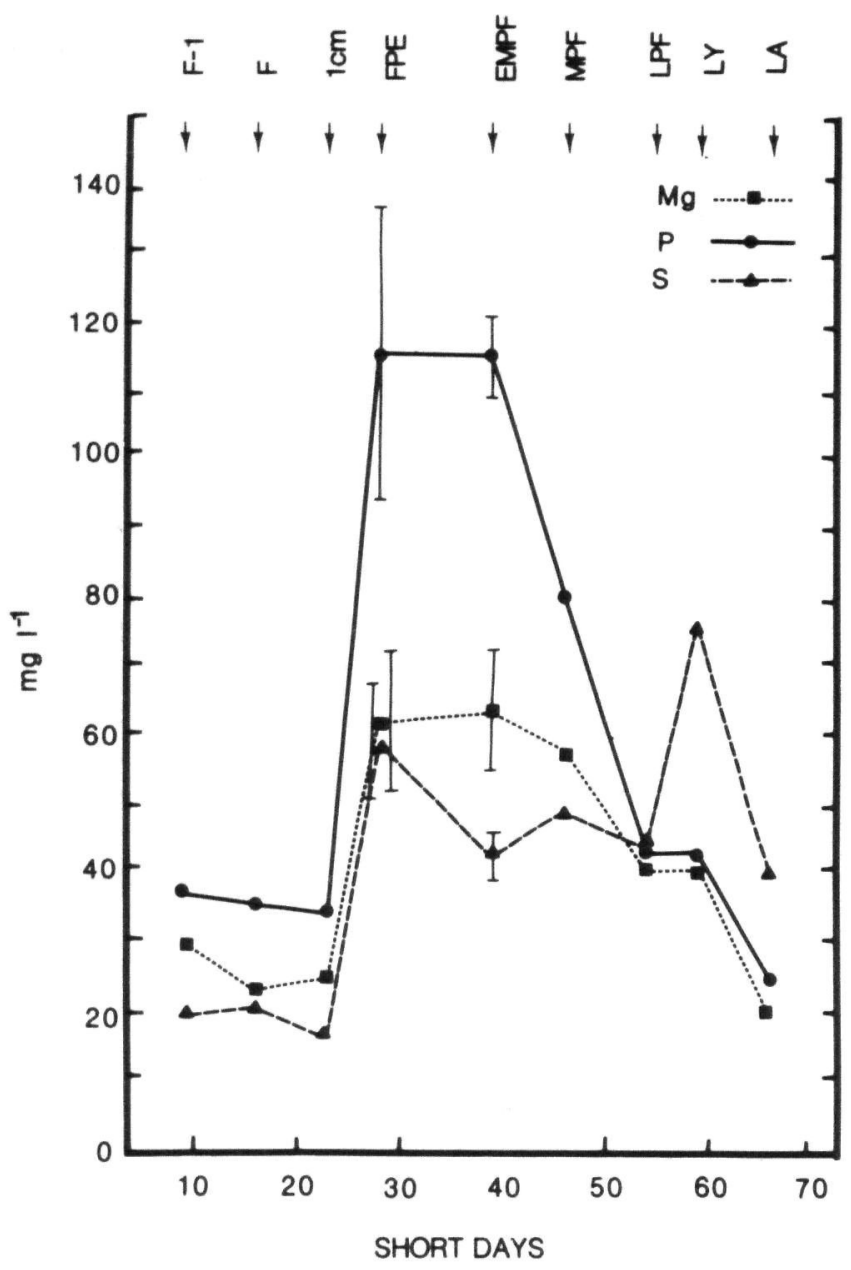

Fig. 4. Changes in the concentration of $M g, P$ and $S$ in xylem sap during the soybean's reproductive phase. Procedure and abbreviations as in Fig. 1.

ently from the above minerals, rising steadily during early reproductive development with a sharper increase during late podfill.

\section{Effects of depodding on xylem element concentrations}

Depodding from full pod extension (pre-podfill) only temporarily delayed the decline in sap volume exuded under pressure in $50 \mathrm{~min}$, and that effect may not have been very significant (Tab. 1). In a different experiment, depodding at this stage produced a greater delay, but the decline in volume still occurred (data not shown). Depodding at late podfill had no effect (data not shown).

In general, depodding at late podfill did not significantly alter the mineral content of xylem sap (data not shown). Depodding at full pod extension (before podfill), however, did influence the mineral composition of the xylem sap, but a high degree of variability was evident in the sap collected late, e.g. early leaf yellowing
(Tab. 1). As noted above, this variability was also exhibited in visible differences among the plants. For the minerals which declined after full pod extension in the above experiments, depodding seemed to inhibit the decline of $\mathrm{K}$ and $\mathrm{Mg}$ but not $\mathrm{P}, \mathrm{Ca}$ or $\mathrm{Mn}$. The changes in $\mathrm{Zn}$ and $\mathrm{Fe}$ were not significantly altered. Depodding also did not alter the overall changes for $\mathrm{B}$ and $\mathrm{Al}$ which increased.

It should be noted that depodding at full extension may have different effects initially (at early-mid podfill) as opposed to later (early leaf yellowing), (e.g. S, Ca, $\mathrm{Fe}, \mathrm{Al}$ ).

Some quantitative and pattern differences may exist among experiments as noted above. Comparing the control plants (podded) in Tab. 1 with those in the figures, it can be seen that there were some differences in the xylem sap concentrations of certain elements; for example, $\mathrm{K}$ at early-mid podfill was $194 \mathrm{mg} \mathrm{l}^{-1}$ in Tab. 1, while it was $320 \mathrm{mg} \mathrm{l}^{-1}$ in Fig. 3. In addition, several differences exist in the pattern of changes (e.g. Zn, Fe, S). The concentrations of elements reported here for xylem sap are fairly close (perhaps slightly higher) to those found for white lupine (also an annual) by Pate and Hocking (1978).

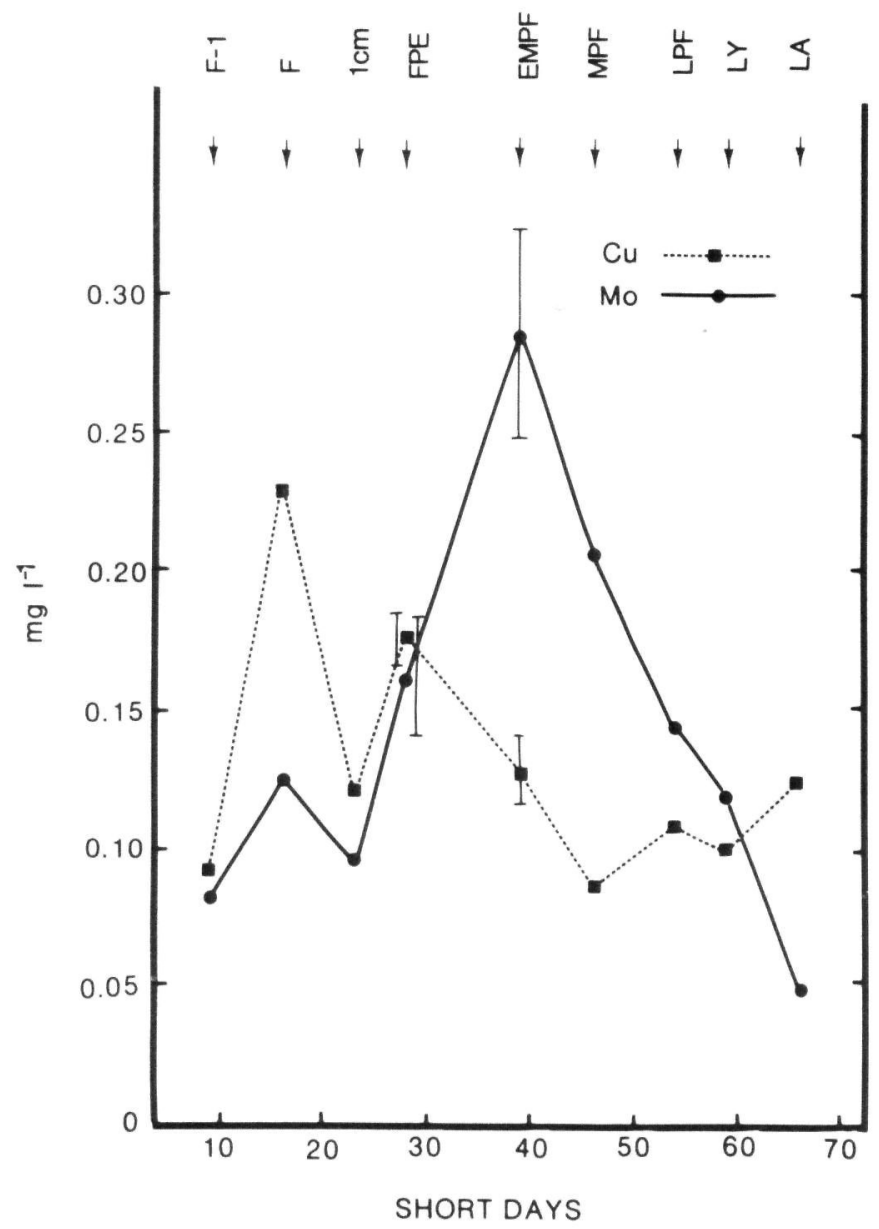

Fig. 5. Changes in the concentration of $\mathrm{Cu}$ and Mo in xylem sap during the soybean's reproductive phase. Procedure and abbreviations as in Fig. 1. 


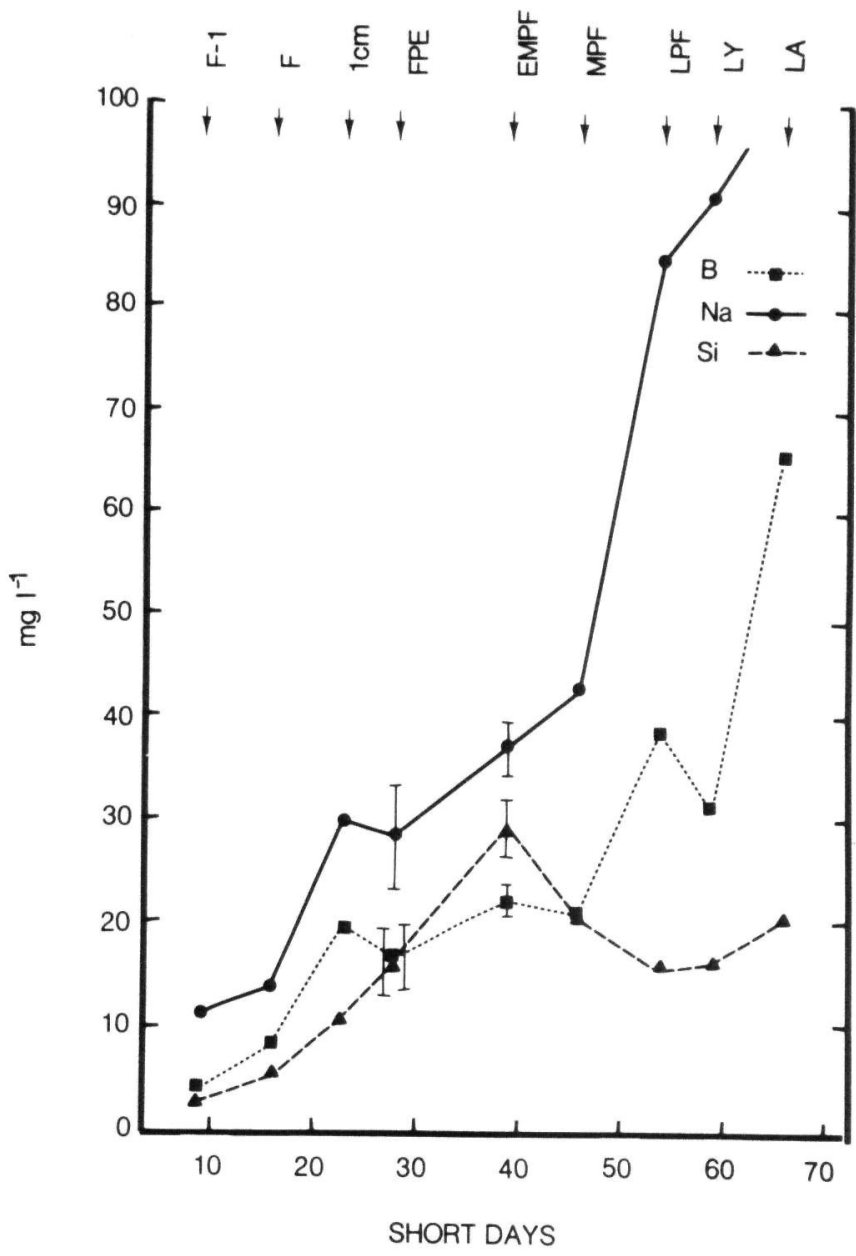

Fig. 6. Changes in the concentration of $\mathrm{B}, \mathrm{Na}$ and $\mathrm{Si}$ in xylem sap during the soybean's reproductive phase. Procedure and abbreviations as in Fig. 1.

\section{Discussion}

\section{Sampling the xylem sap}

The significance of the rise and fall in sap volume extracted in $50 \mathrm{~min}$ (Fig. 1) is not known; however, we suspect it is related to the functioning xylem volume in the rootstock. It is known that root growth ceases during the reproductive phase of soybean; however, the actual timing is variable (Noodén 1980b, 1984). Thus, the functioning volume and the number of young root tips are probably declining. If sap collections were attempted much after leaf abscission, at which time the roots are badly degenerated, sap volumes collected in $50 \mathrm{~min}$ were relatively high and very erratic with no slowdown in rate of sap flow at ca $50 \mathrm{~min}$ as usually occurs. This indicates a release from some restriction of sap flow under pressure. We suggest that our collections may represent an endpoint for emptying or flushing of the rootstock xylem.

We kept the collection times short, because earlier reports indicated that root exudate composition may begin to change within $15-60 \mathrm{~min}$ for $\mathrm{K}$ in tomato sap
(Armstrong and Kirkby 1979) or as early as 20 min after decapitation for nitrogenous constituents in soybean sap (Matsumoto et al. 1977, McClure and Israel 1979). The xylem sap composition from decapitated rootstocks may change due to "starvation" (Pate 1980). In any case, prolonged collection of sap from rootstocks under pressure or vacuum is likely to yield sap, which is dilute relative to normal xylem sap. On the other hand, decapitation is likely to decrease the water flux from the root by removing the transpirational pull, and therefore root bleeding from the stump over a long period may yield a more concentrated sap compared with pressure- or vacuum-extracted sap (Pate 1976, Herridge 1984). Thus, collection from a rootstock under pressure for a short period seems a safe compromise to produce a sample representative of xylem sap and still a good volume yield. We chose a 50-min extraction period, because that seems to represent a short-term endpoint for readily available sap, which roughly approximates the xylem sap volume [estimated from root and stem fresh weights and the approximate fraction of cross-sectional area occupied by xylem, Carlson (1973)] in root xylem at the time of decapitation. We also kept the stump short to minimize xylem to phloem transfer (Pate 1975).

\section{Changes in xylem sap element concentrations during reproductive development}

We have not included $\mathrm{N}$ analyses in this report, because there have been so many reports on the changes in nitrogenous constituents of soybean xylem sap (see Streeter 1985). As with soybean root growth, these reports show differences in the pattern of decline observed, and these probably reflect differences in conditions. Our limited analyses (data not shown) indicate that $\mathrm{N}$ concentration rises from 1 week before flowering to a peak at full pod extension and drops to a low at early-mid podfill followed by a slight rise, which may reflect protein breakdown.

The diversity and complexity of the patterns of change in mineral concentrations in xylem sap stand out readily, but some generalizations can be made. For most elements (e.g. K, Ca, Mg, P, Zn, Fe, Mn, Cu, Mo, $\mathrm{Si}$; Figs 2-5), the concentrations rise during the transition from vegetative to reproductive development or during early reproductive and then decline during podfill. A similar pattern can be seen in photosynthetic rates (Kumura and Naniwa 1965, Dornhoff and Shibles 1970) and $\mathrm{N}_{2}$ fixation (Peat et al. 1981), which probably reflects changes in growth and its supporting assimilation. The other major pattern (B, Na and Al; Figs 6-7) is a continuous increase, sometimes increasing sharply in late podfill. This latter increase may be due to changes in the selective transporters, an increase in permeability and/or decrease in selective exclusion of certain ions in the roots as they age.

For both general patterns, it is clear that each different element may behave somewhat differently, declin- 
Tab. 1. Effect of depodding (from full pod extension) on volume and mineral content of the xylem sap from soybean rootstocks. SE are shown $(n=3)$. ND, not detectable.

\begin{tabular}{|c|c|c|c|c|}
\hline \multirow[t]{2}{*}{ Parameter } & \multicolumn{4}{|c|}{ Stage } \\
\hline & Full extension & Early-mid podfill & Late podfill & Early leaf yellowing \\
\hline \multicolumn{5}{|l|}{ Sap volume $(\mathrm{ml})$} \\
\hline podded & \multirow[t]{2}{*}{$1.43 \pm 0.25$} & \multirow{2}{*}{$\begin{array}{l}1.13 \pm 0.18 \\
1.37 \pm 0.09\end{array}$} & \multirow{2}{*}{$0.94 \pm 0.12$} & \multirow{2}{*}{$0.43 \pm 0.08$} \\
\hline depodded & & & & \\
\hline \multicolumn{5}{|l|}{ Potassium ( $\left.\mathrm{mg} \mathrm{l}^{-1}\right)$} \\
\hline $\begin{array}{l}\text { podded } \\
\text { depodded }\end{array}$ & \multirow[t]{2}{*}{$237 \pm 27$} & \multirow{2}{*}{$\begin{array}{l}194 \pm 5 \\
166 \pm 12\end{array}$} & \multirow{2}{*}{$\begin{array}{l} \pm 27 \\
-\end{array}$} & \multirow{2}{*}{$\begin{aligned} 95 & \pm 40 \\
152 & \pm 56\end{aligned}$} \\
\hline $\begin{array}{l}\text { depodded } \\
\text { Magnesium }\left(\mathrm{mg} \mathrm{l}^{-1}\right)\end{array}$ & & & & \\
\hline \multicolumn{5}{|l|}{ Magnesium ( $\left.\mathrm{mg} \mathrm{l}^{-1}\right)$} \\
\hline depodded & $93 \pm 11$ & $\begin{array}{l}03 \pm 2 \\
59 \pm 4\end{array}$ & $\begin{array}{l} \pm 8 \\
-\end{array}$ & $\begin{array}{ll}28 & \pm 14 \\
68 & +34\end{array}$ \\
\hline \multicolumn{5}{|l|}{ Phosphorus $\left(\mathrm{mg} \mathrm{l}^{-1}\right)$} \\
\hline podded & \multirow{2}{*}{$77 \pm 34$} & $48 \pm 16$ & \multirow{2}{*}{$\begin{array}{l} \pm 8 \\
-\end{array}$} & $13 \pm 7$ \\
\hline $\begin{array}{l}\text { depodded } \\
\text { Calcium }\left(\mathrm{mg}^{-1}\right)\end{array}$ & & \pm 4 & & $21 \pm 8$ \\
\hline \multicolumn{5}{|l|}{ Calcium $\left(\mathrm{mg} \mathrm{l}^{-1}\right)$} \\
\hline $\begin{array}{l}\text { podded } \\
\text { depodded }\end{array}$ & $193 \pm 9$ & $\begin{array}{ll}155 & \pm 10 \\
127 & +11\end{array}$ & $\begin{array}{l} \pm 32 \\
-\end{array}$ & $\begin{array}{ll}89 & \pm 29 \\
96 & \pm 59\end{array}$ \\
\hline Manganese $\left(\mathrm{mg} \mathrm{l}^{-1}\right)$ & & $127-11$ & & $90 \quad 159$ \\
\hline $\begin{array}{l}\text { podded } \\
\text { depodded }\end{array}$ & $0.92 \pm 0.22$ & $0.94 \pm 0.05$ & $0.47 \pm 0.15$ & ND \\
\hline $\begin{array}{l}\text { depodaed } \\
\text { Zinc }\left(\mathrm{mg} \mathrm{l}^{-1}\right)\end{array}$ & & $0.89 \pm 0.07$ & - & ND \\
\hline podded & $1.5 \pm 0.4$ & $1.9 \pm 0.3$ & $2.1 \pm 0.3$ & $2.7 \pm 0.7$ \\
\hline depodded & & $1.1 \pm 0.1$ & - & $2.5 \pm 0.4$ \\
\hline Iron $\left(\mathrm{mg} \mathrm{l}^{-1}\right)$ & & & & \\
\hline podded & $2.3 \pm 0.1$ & $1.7 \pm 0.2$ & $1.0 \pm 0$ & $1.51 \pm 0.2$ \\
\hline depodded & & $1.1 \pm 0.1$ & - & $4.9 \pm 3.7$ \\
\hline $\begin{array}{l}\text { Copper }\left(\mathrm{mg} \mathrm{l}^{-1}\right) \\
\text { podded }\end{array}$ & $0.17 \pm 0.06$ & & $018+004$ & $044+020$ \\
\hline depodded & $0.17-0.00$ & $0.18 \pm 0.01$ & $\begin{array}{c}0.18 \pm 0.04 \\
-\end{array}$ & $\begin{array}{l}0.44 \pm 0.20 \\
0.34 \pm 0.07\end{array}$ \\
\hline Sulfur $\left(\mathrm{mg} \mathrm{l}^{-1}\right)$ & & & & \\
\hline podded & $57 \pm 13$ & $52 \pm 4$ & \pm 12 & \pm 25 \\
\hline depodded & & $33 \pm 4$ & - & \pm 25 \\
\hline $\begin{array}{l}\text { Boron }\left(\mathrm{mg} \mathrm{l}^{-1}\right) \\
\text { podded }\end{array}$ & & & & \\
\hline $\begin{array}{l}\text { podded } \\
\text { depodded }\end{array}$ & $10.1 \pm 2.5$ & $\begin{array}{r}14.6 \pm 6.5 \\
8.4+0.7\end{array}$ & $16.9 \pm 6.3$ & $34.0 \pm 7.0$ \\
\hline Aluminum $\left(\mathrm{mg} \mathrm{l}^{-1}\right)$ & & $0.4 \pm 0.7$ & - & $29.0 \pm 15.7$ \\
\hline podded & $2.2 \pm 0.6$ & $1.6 \pm 0.2$ & $3.2 \pm 0.6$ & $7.6 \pm 2.8$ \\
\hline depodded & & $3.1 \pm 0.5$ & - & $7.6 \pm 1.2$ \\
\hline
\end{tabular}

ing and peaking at different developmental stages. Thus, it seems that the different elements may be transported and regulated independently. Other lines of evidence also indicate that accumulation of the different elements may be regulated separately (Harper 1971, Kollman et al. 1974, Derman et al. 1978, Noodén 1984).

\section{Xylem sap element concentrations as a measure of element flux through the xylem}

The mineral values given here are concentrations and need not necessarily reflect net fluxes; that would, of course, be a product of concentration and volume moved. The volume factor should be the same (barring differences in molecular sieving) for all the elements, so that should not produce any differences among the elements. Stomatal resistance and transpiration in the leaves of whole soybean plants appear to remain fairly constant in unstressed plants until quite late in devel- opment (Kumara and Naniwa 1965, Woodward and Rawson 1976, Noodén 1985) and, once vegetative growth has ceased, the leaf area remains constant until close to leaf abscission in monocarpic senescence (Okatan et al. 1981). Thus, at least in podded plants, mineral concentration in the xylem sap probably provides a reasonable measure of relative flux into the shoot system. The flux of most minerals (e.g. K, Mn, Ca, Mg, P, Zn, $\mathrm{Fe}, \mathrm{Cu}, \mathrm{Mo}, \mathrm{Si}$ ) through the xylem declines some time during the reproductive phase, while others ( $\mathrm{B}, \mathrm{Na}, \mathrm{Al}$ and possibly S) do not decrease. Of course, the supply of minerals to the developing pods would later require transfer from the xylem to the phloem, which would differ for the elements, but this may occur mainly in the leaves (Pate 1975, 1976, Pate and Hocking 1978, Noodén 1984, 1985).

\section{Effects of depodding on xylem sap minerals}

Interestingly, while depodding does prevent the rapid death of the plant, it prevents the decline in sap concen- 


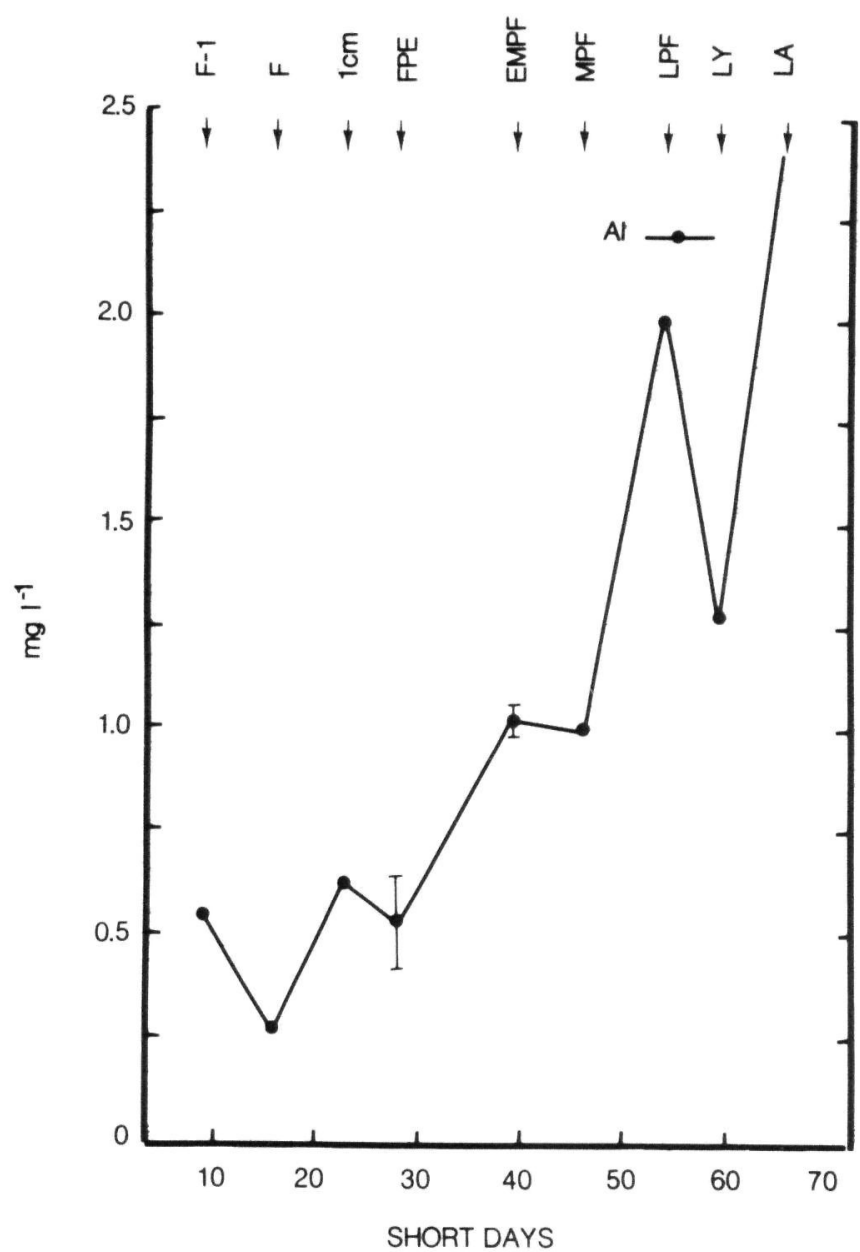

Fig. 7. Changes in the concentration of Al in xylem sap during the soybean's reproductive phase. Procedure and abbreviations as in Fig. 1.

trations for some minerals and not others. Depodding also increases stomatal resistance (Koller and Thorne 1978, Setter et al. 1980) and thereby water flux up into the shoot. Depodding, therefore, has the potential to produce a reverse dilution effect, i.e. increased mineral concentrations in the sap rather like decapitation does (Pate 1976, Herridge 1984), but no such effect is evident here. Indeed, most elements actually continue their decline despite depodding, while others are unaltered. Depodding and partial depodding may or may not alter mineral accumulation in the shoot system depending on the element and circumstances (Kollman et al. 1974, Derman et al. 1978); however, reconciling all the effects on xylem flux and shoot accumulation will require a concerted study of both on the same batch of plants.

Depodding also increases or at least prevents the decline in root growth (Noodén 1984), but it does not prevent the decrease in sap volume delivered from the root during $50 \mathrm{~min}$ of pressure. Perhaps depodding increases the number of root tips more than it alters the rootstock xylem volume. Since depodding affects accumulation of different elements differently, it seems unlikely that de- podding acts through such an unselective mechanism such as the alteration of water flow. The pods and not decreased mineral flux seem to be most important in inducing leaf senescence (Neumann et al. 1983, Noodén 1985), so it probably does not matter if the mineral flux declines in depodded plants. Moreover, there is probably little need for a continued influx of mineral nutrients, because little growth takes place in the shoots of these depodded plants (Noodén 1984). The fact that the accumulation of some mineral nutrients does decline in depodded plants is interesting and probably reflects a metabolic adjustment to decreased consumption (Noodén 1984).

\section{Conclusion}

Finally, studies on explants indicate that a declining mineral flux up through the xylem could be a factor, though probably not a cause, in monocarpic senescence of soybean (Neuman et al. 1983, Noodén 1985). The present paper shows that the xylem sap concentrations of most mineral nutrients drop during podfill and therefore supports the idea that a decrease in mineral flux during podfill prepares the leaves for a more direct senescence-inducing action of the pods.

Acknowledgements - We thank Ms Patricia Arscott for her technical assistance. This study was supported in part by grant no. PCM-8302707 from the U.S. National Science Foundation.

\section{References}

Armstrong, M. J. \& Kirkby, E. A. 1979. Estimation of potassium recirculation in tomato plants by comparison of the rates of potassium and calcium accumulation in the tops with their fluxes in the xylem stream. - Plant Physiol. 63: 1143-1148.

Carlson, J. B. 1973. Morphology. - In Soybeans: Improvement, Production, and Uses (B. E. Caldwell, ed.), pp. 17-95. Am. Soc. Agron., Inc., Madison, WI. ISBN 0089118-017-6.

Derman, D. B., Rupp, D. C. \& Noodén, L. D. 1978. Mineral distribution in relation to fruit development and monocarpic senescence in Anoka soybeans. - Am. J. Bot. 65: 205213.

Dornhoff, G. M. \& Shibles, R. M. 1970. Varietal differences in net photosynthesis of soybean leaves. - Crop Sci. 10: $42-45$.

Garrison, F. R., Brinker, A. M. \& Noodén, L. D. 1984. Relative activities of xylem-supplied cytokinins in retarding leaf senescence and sustaining pod development. - Plant Cell Physiol. 25: 213-224.

Harper, J. E. 1971. Seasonal nutrient uptake and accumulation patterns in soybeans. - Crop Sci. 11: 347-350.

Herridge, D. F. 1984. Effects of nitrate and plant development on the abundance of nitrogenous solutes in root-bleeding and vacuum-extracted exudates from soybean. - Crop Sci. 25: $173-179$.

Koller, H. R. \& Thorne, J. H. 1978. Soybean pod removal alters leaf diffusion resistance and leaflet orientation.- Crop Sci. 18: 305-307

Kollman, G. E., Streeter J. G., Jeffers, D. L. \& Curry, R. B. 1974. Accumulation and distribution of mineral nutrients carbohydrate and dry matter in soybean as influenced by reproductive sink size. - Agron. J. 66: 519-554. 
Kumura, A. \& Naniwa, I. 1965. Studies on dry matter production of soybean plant. I. Ontogenic changes in photosynthetic and respiratory capacity of soybean plant and its parts. - Proc. Crop Sci. Soc. Jpn 33: 467-471.

Leopold, A. C., Niedergang-Kamien, E. \& Janick, J. 1959. Experimental modification of plant senescence. - Plant Physiol. 34: 570-573.

Lindoo, S. J. \& Noodén, L. D. 1976. The interrelation of fruit development and leaf senescence in 'Anoka' soybeans. Bot. Gaz. 137: 218-223.

Matsumoto, T., Yatazawa, M. \& Yamamoto, Y. 1977. Distribution and change in the contents of allantoin and allantoic acid in developing nodulating and non-nodulating soybean plants. - Plant Cell Physiol. 18: 353-359.

McClure, P. R. \& Israel, D. W. 1979. Transport of nitrogen in the xylem of soybean plants. - Plant. Physiol. 64: 411-416.

deMooy, C. J., Pesek, J. \& Spaldon, E. 1973. Mineral nutrition. - In Soybeans: Improvement, Production, and Uses (B. E. Caldwell, ed.), pp. 267-352. Am. Soc. Agron., Inc., Madison, WI. ISBN 0-089118-017-6.

Neumann, P. M., Tucker, A. T. \& Noodén, L. D. 1983. Characterization of leaf senescence and pod development in soybean explants. - Plant Physiol. 72: 182-185.

Noodén, L. D. 1980a. Regulation of senescence. - In World Soybean Research Conference II: Proceedings (F. T. Corbin, ed.), pp. 139-152. Westview Press, Boulder, CO. ISBN 0-89158-678-4.

- 1980b. Senescence in the whole plant. - In Senescence in Plants (K. V. Thimann, ed. ), pp. 219-258. CRC Press, Boca Raton, FL. ISBN 0-8493-5803-5.

- 1984. Integration of soybean pod development and monocarpic senescence. - Physiol. Plantarum 62: 273-284.

- 1985. Regulation of senescence. Cytokinin and minerals. In World Soybean Research Conference. III: Proceedings (R. Shibles, ed. ), pp. 891-900. Westview Press, Boulder, CO. ISBN 0-8133-0091-6.

Ohlrogge, A. J. 1963. Mineral nutrition of soybeans. In The
Soybean (A. G. Norman, ed.), pp. 125-160. Academic Press, New York.

Okatan, Y., Kahanak, G. M. \& Noodén, L. D. 1981. Characterization and kinetics of soybean maturation and monocarpic senescence. - Physiol. Plantarum 52: 330-338.

Pate, J. S. 1975. Exchange of solutes between phloem and xylem and circulation in the whole plant. - In Encyclopedia of Plant Physiology, New Series (M. H. Zimmerman and J. A. Milburn, eds), Vol. 1, pp. 451-473. Springer-Verlag, New York. ISBN 0-387-07314-0.

Pate, J. S. 1976. Nutrient mobilization and cycling: Case studies for carbon and nitrogen in organs of a legume. - In Transport and Transfer Processes in Plants (I. F. Wardlaw and J. B. Passioura, eds), pp. 447-462. Academic Press, New York.

- 1980. Transport and partitioning of nitrogenous solutes. Annu. Rev. Plant Physiol. 31: 313-340.

- \& Hocking, P. J. 1978. Phloem and xylem transport in the supply of minerals to a developing legume (Lupinus albus L.) fruit. - Ann. Bot. 42: 911-921.

Peat, J. R., Minchin, F. R., Jeffcoat, B. \& Summerfield, R. J. 1981. Young reproductive structures promote nitrogen fixing in soya-bean. - Ann. Bot. 48: 177-182.

Setter, T. L., Brun, W. A. \& Brenner, M. L. 1980. Stomatal closure and photosynthetic inhibition in soybean leaves induced by petiole girdling and pod removal. - Plant. Physiol. 65: 884-887

Streeter, J. G. 1985. Export of nitrogenous compounds from soybean roots. - In World Soybean Reserarch Conference. III: Proceedings (R. Shibles, ed.), pp. 756-764. Westview Press, Boulder, CO. ISBN 0-8133-0091-6.

Woodward, R. G. \& Rawson, H. M. 1976. Photosynthesis and transpiration in dicotyledonous plants. II. Expanding and senescing leaves of soybean. - Aust. J. Plant Physiol. 3: $257-267$.

Zimmerman, M. H. 1983. Xylem Structure and the Ascent of Sap. - Springer-Verlag, Berlin. pp. 66-82. ISBN 0-38712268-0. 
This document is a scanned copy of a printed document. No warranty is given about the accuracy of the copy. Users should refer to the original published version of the material. 